\title{
LA-UR $95-871$
}

Los Alamos National Laboratory is operated by the University of Califomia for the United States Department of Energy under contract W-7405-ENG36.

TITLE: $\quad$ MULTIPLE EPISODES OF ZEOLITE DEPOSITION IN FRACTURED SILICIC TUFF

$\begin{array}{ll}\text { AUTHOR(S): } & \text { Barbara Carlos, EES-1 } \\ & \text { Steve J. Chipera, EES-1 }\end{array}$

Marjorie G. Snow, EES-1

SUBMITTED TO: $\quad$ A.A. Balkema Publishers

8th International Symposium on Water-Rock Interaction Vladivostok, Russia, August 1328,1995

\section{DISCLAIMER}

This report was prepared as an account of work sponsored by an agency of the United States Government. Neither the United States Government nor any agency thereof, nor any of their employees, makes any warranty, express or implied, or assumes any legal liability or responsibility for the accuracy, completeness, or usefulness of any information, apparatus, product, or process disclosed, or represents that its use would not infringe privately owned rights. Reference herein to any specific commercial product, process, or service by trade name, trademark, manufacturer, or otherwise does not necessarily constitute or imply its endorsement, recommendation, or favoring by the United States Government or any agency thereof. The views and opinions of authors expressed herein do not necessarily state or reflect those of the United States Government or any agency thereof.

By acceptance of this article, the publisher recognizes that the U.S. Government retains a nonexclusive, royalty-free license to publish or reproduce the published form of this contribution, or to allow others to do so, for U.S. Govemment purposes.

The Los Alamos National Laboratory requests that the publisher identify this article as work performed under the auspices of the U.S. Department of Energy.
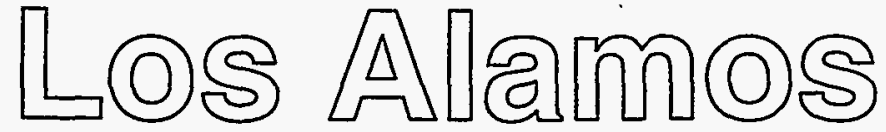

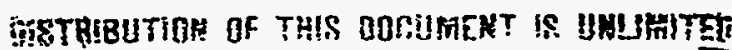

Los Alamos National Laboratory Los Alamos, New Mexico 87545 
Barbara A. Carlos, Steve J. Chipera, and Marjorie G. Snow

Los Alamos National Laboratory, Mail Stop D462, Los Alamos, NM 87545

\begin{abstract}
Fractures in silicic tuffs above the water table at Yucca Mountain, Nevada, USA contain two morphologies of heulandite with different compositions. Tabular heulandite is zoned, with Sr-rich cores and $\mathrm{Mg}$-rich rims. Later prismatic heulandite is nearly the same composition as the more magnesian rims. Heulandite and stellerite may occur between layers of calcite, and calcite occurs locally between generations of heulandite. Thermodynamic modeling, using estimated thermodynamic data and observed chemical compositions for heulandite and stellerite, shows that stellerite is the favored zeolite unless Ca concentrations are reduced or Mg and/or Sr concentrations are significantly elevated above current Yucca Mountain waters.
\end{abstract}

\section{INTRODUCTION}

Yucca Mountain, in southwest Nevada, USA is composed of a $>1.5 \mathrm{~km}$-thick sequence of silicic tuffs and subordinate lavas (Scott et al., 1983; Carr et al., 1986) ranging in age from $12 \mathrm{my}$ to $>14 \mathrm{my}$ (Sawyer et al., 1994). Yucca Mountain is being investigated as a potential high-level nuclear waste repository since a repository could be located within devitrified tuff $>200 \mathrm{~m}$ below the surface of the mountain yet still be $150 \mathrm{~m}$ above the water table, and because the zeolitic tuffs beneath the potential repository provide a natural barrier to the migration of some radionuclides. Fracture-lining minerals within the unsaturated zone provide information on potential flow paths both toward and away from the potential repository; knowledge of the distribution of fracture-lining minerals is also needed to model reactions along flow paths at elevated temperatures resulting from waste emplacement.

Fracture coatings within the predominantly nonzeolitic Paintbrush Group vary both with depth and laterally across Yucca Mountain, with the most abundant fracture-lining minerals consisting of silica polymorphs (quartz, tridymite, cristobalite, opal-CT), calcite, zeolites (stellerite, heulandite, mordenite), and $\mathrm{Mn}$-oxides (lithiophorite and rancieite), with lesser amounts of smectite, chain clays, fluorite, calcic amphibole, and Fe-oxides (Carlos et al., 1991, and in press). The general sequence of deposition is 1) tridymite and quartz on early fractures and lithophysal cavities, often with hematite blades and/or calcic amphibole; 2) fine grained mordenite and crusts of clay and/or manganese oxide minerals on curviplanar cooling fractures in both devitrified and vitrophyric

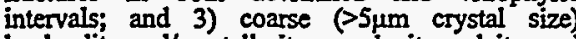
heulandite and/or stellerite, mordenite, calcite, and fine-grained clays on rougher fractures and over the minerals coating earlier fractures. Fluorite and/or opal may occur with calcite in fractures and lithophysal cavities, particularly in. shallower intervals. Stellerite and mordenite may occur over lithophysal coatings in deeper intervals. Many of the fracture coatings in the unsaturated zone were deposited early in the cooling history of the tuff (11.5-12.5 My ago), but some of the calcite, clays, and zeolites in the Paintbrush Group are more recent and therefore provide information on flow paths and transport within fractures that would be useful in predicting the behavior of the mountain after emplacement of radioactive waste.

Multiple episodes of zeolite deposition are suggested by at least two compositions and morphologies of heulandite coexisting in fractures in the unsaturated zone. Whelan et al. (1994) have shown using $C$ and $O$ isotopic data that calcites in unsaturated intervals precipitated from meteoric water that had interacted with soil at the surface. Carbon-14 dates obtained from calcites in the unsaturated zone range from $20.9 \mathrm{Ka}$ to $>51 \mathrm{Ka}$ (limit of the method). To better understand zeolite deposition in fractures in the unsaturated zone, fractures containing more than one morphology of heulandite, and fractures containing both calcite and zeolite were examined. In addition, thermodynamic modeling was performed to determine the nature of changing conditions required to precipitate the sequence of fracture coatings that is present at Yucca Mountain.

\section{METHODS}

Fracture coatings from drill cores at and near Yucea Mountain were examined using a binocular 
microscope at up to $50 \times$ magnification, and fragments from selected fractures were examined using an ISI scanning electron microscope (SEM) and a Tracor Northern ADEM SEM. Backscattered electron (BSE) images of polished grain mounts and of thin sections of zeolitic coatings were used to identify zoning in the zeolites. Quantitative chemical analyses of fracture-coating zeolites were obtained using a Cameca SX-50 microprobe.

To conduct thermodynamic modeling, a consistent set of thermodynamic data utilizing representative mineral compositions from the Paintbrush Tuff (Table 1 and Chipera et al., in press) was estimated using the methods of Berman and Brown (1985), Chermak and Rimstidt (1989) and Holland (1989). Applying the Ge0-Calc PTA program of Brown et al. (1989), mineral-stability diagrams were calculated at various temperatures, siliea activities, and for varying activities of the ionic species in the groundwater. Calculations were conducted projecting from water (activity $=1$ ) and any reaction or product cations were exchanged with the liquid phase. In the calculations, cation concentrations in the fluid phase were assumed to initially approximate the current concentrations measured in Yucca Mountain ground water (Kerrisk, 1987). Cation concentrations may be buffered by other reactions occurring in the natural system independent of the reactions involving zeolites (e.g., excess $\mathrm{Ca}^{2+}$ consumed to form calcite). Pressure was constrained such that all calculations were conducted on the liquid side of the water liquid-vapor curve, and $\mathrm{pH}$ values used for the calculations were constrained to $\approx 8$, a value that is representative of present-day waters at Yucca Mountain (Kerrisk, 1987). Additional thermodynamic data and methodology used are described in Chipera et al. (in press).

\section{RESULTS AND DISCUSSION}

Fractures in the devitrified Topopah Spring Tuff contain the zeolites heulandite, stellerite, and mordenite. Heulandite occurs in fractures above the water table as both tabular and prismatic crystals. The tabular crystals are larger (usually 100-200 $\mu \mathrm{m}$ in diameter) and generally are limited to an interval of a few tens of meters above the basal vitrophyre. Chemical zonation in the tabular crystals is visible in BSE (SEM) images. Prismatic heulandite in BSE (SEM) images. Prismatic heulandite fractures and are smaller (10-50 $\mu \mathrm{m}$ long). Zonation is not evident in BSE images of prismatic crystals. Since most prismatic crystals are too small to analyze by electron microprobe it is not known if all sizes of prismatic crystals have the same composition. In fractures that contain both prismatic and tabular heulandite, the prismatic crystals partially overlie the tabular crystals.

Zoned tabular heulandites have cores richer in $\mathrm{Sr}$, $\mathrm{Ca}$, and $\mathrm{Na}$, and rims enriched in $\mathrm{Mg}$. Cation compositions of the cores of the tabular crystals

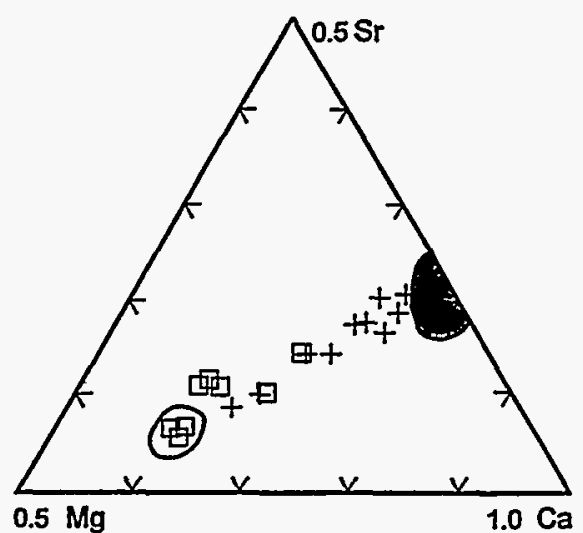

Figure 1. Ternary plot based on number of exchangeable cations, showing chemistry of prismatic heulandite crystals (open circle) and chemical zonation of tabular heulandite crystals. Shaded area represents the cores of tabular crystals, open boxes are rims and + are intermediate zones $20-40 \mu \mathrm{m}$ beneath the rims.

analyzed in this study ( 3 samples from 2 drill cores) cluster tightly on the ternary diagram in Fig. 1. The prismatic heulandites ( 4 crystals from one sample) have the same composition as the rims of the tabular heulandite coexisting in that sample. Rims of tabular crystals from other samples and the zones between rims and cores plot along a trend between these two compositions. Representative compositions of the SI-rich core, the Mg-rich rim and prismatic crystals from the same interval are and prismatic cryst

Mordenite occurs both with and over heulandite (both morphologies), and may have been deposited continuously or in several episodes. Stellerite occurs as single crystals or as sprays of crystals by themseives, with prismatic heulandite, with mordenite, and rarely, with tabular heulandite.

Calcite overlies tabular heulandite in a few fractures and, in at least two samples, small prismatic zeolites occur on top of that calcite. Larger prismatic heulandites in the same samples are not in contact with the calcite. Some stellerites occur over tridymite or on matrix under calcite and appear to have been deposited early in the cooling history of the tuff. Other stellerites occur with prismatic heulandite over calcite, and were therefore deposited after that calcite and after the tabular heulandite that preceded prismatic heulandite. In some samples, additional calcite coats the stellerite + heulandite. Differences in chemical composition in the stellerite have not been observed, but that may be because the structure of stellerite allows for little substitution. As there were several episodes of calcite deposition, relationship to calcite does not establish age of the zeolite unless that particular 
Table 1. Chemical analyses of zeolites.

\begin{tabular}{|c|c|c|c|c|}
\hline & $\begin{array}{c}\text { Tabular } \\
\text { core }\end{array}$ & $\begin{array}{l}\text { Leulandi } \\
\text { Tabular } \\
\text { rim }\end{array}$ & $\begin{array}{l}\text { Pris- } \\
\text { matic }\end{array}$ & $\begin{array}{l}\text { Steller- } \\
\text { ite }\end{array}$ \\
\hline $\begin{array}{l}\mathrm{SiO}_{2} \\
\mathrm{Al}_{2} \mathrm{O}_{3} \\
\mathrm{MgO} \\
\mathrm{CaO} \\
\mathrm{SrO} \\
\mathrm{Na}_{2} \mathrm{O} \\
\mathrm{K}_{2} \mathrm{O} \\
\text { Total }\end{array}$ & $\begin{array}{c}64.67 \\
15.34 \\
0.08 \\
5.86 \\
2.53 \\
0.64 \\
0.41 \\
89.53\end{array}$ & $\begin{array}{c}65.06 \\
15.61 \\
1.86 \\
4.83 \\
1.06 \\
0.22 \\
0.17 \\
88.81\end{array}$ & $\begin{array}{c}64.46 \\
14.82 \\
1.86 \\
4.73 \\
0.88 \\
0.29 \\
0.17 \\
87.21\end{array}$ & $\begin{array}{c}64.60 \\
15.33 \\
\overline{8.29} \\
\overline{0.15} \\
0.08 \\
88.45\end{array}$ \\
\hline $\begin{array}{l}\mathrm{Si} \\
\mathrm{Al} \\
\mathrm{Mg} \\
\mathrm{Ca} \\
\mathrm{S} \\
\mathrm{Na} \\
\mathrm{K} \\
\mathrm{O} \\
\mathrm{Si} / \mathrm{Al}\end{array}$ & $\begin{array}{c}28.18 \\
7.88 \\
0.05 \\
2.74 \\
0.64 \\
0.54 \\
0.23 \\
72 \\
3.58\end{array}$ & $\begin{array}{c}28.12 \\
7.95 \\
1.20 \\
2.24 \\
0.27 \\
0.18 \\
0.09 \\
72 \\
3.54\end{array}$ & $\begin{array}{c}28.32 \\
7.67 \\
1.22 \\
2.23 \\
0.22 \\
0.25 \\
0.10 \\
72 \\
3.69\end{array}$ & $\begin{array}{c}28.12 \\
7.87 \\
\overline{3.87} \\
\overline{0.13} \\
0.04 \\
72 \\
3.58\end{array}$ \\
\hline
\end{tabular}

\section{UE-25a\#1 1243}

${ }^{2}$ USW G-2 1505

calcite has been dated.

Between deposition of the tabular heulandite and prismatic heulandite the fluid composition must have changed. The compositional boundaries between rims and cores of tabular crystals are not shap growth boundaries, but somewhat variable (Fig. 2) and appear to indicate diffusion from the edges and along cracks or imperfections in the crystals. The zonation is not of equal width around the edges of crystals and appears to have been influenced by crystallographic orientation. A sharper and more regular zonation boundary would have resulted from overgrowths on the tabular crystals. SEM images indicate that when more

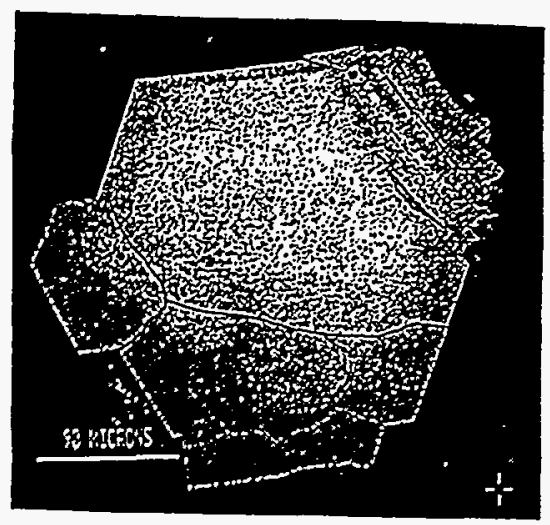

Figure 2. Backscattered electron SEM image of zoned tabular heulandite showing irregular pattern of $\mathrm{Mg}$ enrichment (darker areas). magnesian heulandite was deposited on existing tabular crystals, it formed prismatic crystals on the surface of the tabular crystals. The intermediate compositions in the visibly zoned areas between the rims and the core, and the intermediate compositions of some rims could indicate a gradual change in composition of the fluid, but the pattern of $\mathrm{Mg}$ distribution observed in BSE images and the consistent relationship of chemistry with mophology suggest two separate intervals of heulandite deposition with different fluid compositions and diffusion into the tabular crystals rather than a gradual change in fluid composition over time.

Results of thermodynamic modeling show that silica activity has a strong control over. whether stellerite and/or heulandite form relative to other zeolites (e.g., clinoptilolite and mordenite). Figure 3 shows the effect of silica activity and the calculated equilibria using $\log \left[\left(a \mathrm{~K}^{+}\right)^{2} / a \mathrm{Ca}^{2+}\right]$ vs. $\log \left[\left(a \mathrm{Na}^{2}\right)^{2} / a^{2} \mathrm{Ca}^{2}\right]$ for zeolites found at Yucca Mountain. Present-day cation concentrations in Yucca Mountain waters are plotted on the figure for reference. At elevated silica activities (e.g., equilibrated with amorphous silica), clinoptilolite and mordenite are the zeolites that are most likely to form. At lower silica activities (e.g., equilibrated with cristobalite or tridymite) stellerite and/or heulandite are the zeolites most likely to form. Stellerite and heulandite coexist in some fractures and have similar Si/Al ratios, so it is not surprising that modeling of silica activities does not differentiate between the two minerals. Silica activities in the fractures are most likely in equilibrium with cristobalite or quartz as indicated by the coexistence of these silica polymorphs with

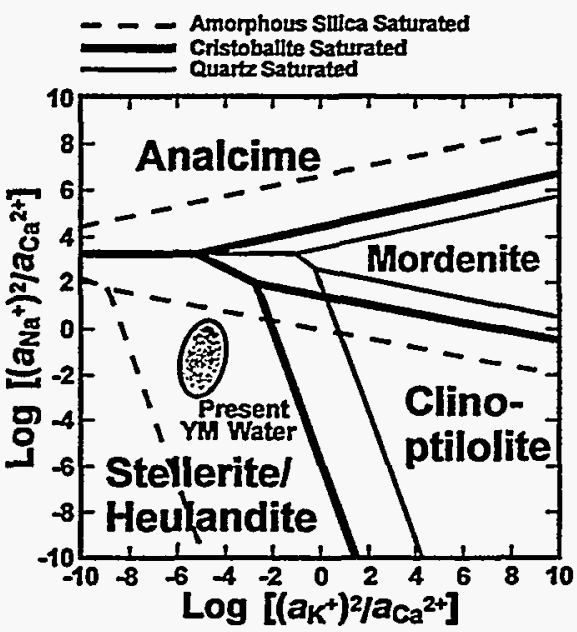

Figure 3. $\mathrm{Log}\left[\left(a \mathrm{~K}^{+}\right)^{2} / a \mathrm{Ca}^{2+}\right]$ vs. $\log \left[\left(a \mathrm{Na}^{+}\right)^{2} / a_{\mathrm{Ca}}^{2+}\right]$ diagrams for zeolite phases found at Yucca Mountain constructed at $75^{\circ} \mathrm{C}$ and at variable silica activities. 
stellerite and heulandite in some fractures. Figure 3 also demonstrates the influence of cation composition on the formation of individual zeolite species. The exact stability fields can differ markedly in response to the cation ratios in the zeolites used for the calculations.

The dominant control on heulandite vs. stellerite deposition was found to be the concentration of the various dissolved cation species in the ground water. In the calculations, stellerite was the stable zeolite to form unless $\mathrm{Ca}$ concentration was significantly reduced with respect to current concentrations, or $\mathrm{Sr}$ and/or $\mathrm{Mg}$ content was increased. The presence of calcite coexisting in the fractures allows ready calculation of $\mathrm{Ca}$ concentration given $\cdot \mathrm{pH}$, temperature, and bicarbonate concentration, and constrains $\mathrm{Ca}^{2+}$ to concentrations roughly equivalent to current Yucea Mountain values.

Increasing temperature to $175^{\circ} \mathrm{C}$ in the calculations showed only minor effects. With increased temperature at a given silica saturation, the stability fields for mordenite and clinoptilolite decrease slightly as the stellerite/heulandite stability fields increases. Increasing temperature also affected the calcite-Ca ${ }^{2+}$ equilibria such that it reduced the activity of $\mathrm{Ca}^{2+}$, which would favor the deposition of heulandite at higher temperatures.

\section{CONCLUSIONS}

Chemical compositions of heulandite suggest two generations of zeolite deposition in these fractures, and morphological evidence suggests that there may be three; the presence of stellerite and/or heulandite both over and under calcite establishes that there were at least two episodes. Whether all zeolite deposition occurred soon after deposition of the tuff, or whether some zeolite deposition is more recent may be determined by dating of calcite that occurs under some zeolites.

Results of thermodynamic modeling show that although silica activity controls whether stelleriteheulandite or clinoptilolite-mordenite will form, it has little effect on stellerite-heulandite equilibria. Activities of the cation species in the groundwater exert the most control on the formation of stellerite vs. heulandite. Stellerite is the favored zeolite to form unless $\mathrm{Ca}$ concentrations are significantly reduced or $\mathrm{Mg}$ and/or Sr concentrations significantly elevated, whereupon heulandite is favored. Since $\mathrm{Ca}$ concentration was buffered by the abundant calcite seen in the fractures, it appears that the $\mathrm{Mg}$ and $\mathrm{Sr}$ concentrations were elevated to values greater than in present Yucca Mountain groundwaters. This could be accomplished through either increased dissolution in the rocks or concentration of dissolved species in solution.

\section{REFERENCES}

Berman, R.G. \& T.H. Brown 1985. Heat capacity of minerals in the system $\mathrm{Na}_{2} \mathrm{O}-\mathrm{K}_{2} \mathrm{O}-\mathrm{CaO}-\mathrm{MgO}-$ $\mathrm{FeO}-\mathrm{Fe}_{2} \mathrm{O}_{3}-\mathrm{Al}_{2} \mathrm{O}_{3}-\mathrm{SiO}_{2}-\mathrm{TiO}_{2}-\mathrm{H}_{2} \mathrm{O}-\mathrm{CO}_{2}$ : representation, estimation, and high temperature extrapolation. Contr. Mineral. \& Petrol. 89:168183.

Brown, T.H., R.G. Berman \& E.H. Perkins 1989. PTA-SYSTEM: A Ge0-Calc software package for the calculation and display of activitytemperature-pressure phase diagrams. Amer. Mineral. 74:485-487.

Carlos, B.A., S.J. Chipera, D.L. Bish \& R. Raymond (in press). Distribution and chemistry of fracture-lining zeolites at Yucca Mountain, Nevada Conference Volume, Zeolite '93, D.W. Ming \& F.A. Mumpton, eds.

Carlos, B.A., D.L. Bish \& S.J. Chipera 1991 Fracture-lining minerals in the Lower Topopah Spring Tuff at Yucca Mountain. Proc. $2^{\text {nd }}$ Amm Int. Conf. High Level Radioactive Waste Manag: 486-493., Las Vegas, Nevada.

Carr, W.J., F.M. Byers Jr. \& P.P. Orkild 1986 Stratigraphic and volcano-tectonic relations of Crater Flat Tuff and some older volcanic units, Nye County, Nevada. U.S. Geol. Surv. Prof. Paper, 1323.

Chermak, J.A. \& J.D. Rimstidt 1989. Estimating the thermodynamic properties $\left(\Delta \mathrm{G}^{\circ}\right.$, and $\Delta \mathrm{H}^{\circ}$ ) of silicate minerals at $298 \mathrm{~K}$ from the sum of polyhedral contributions. Amer. Mineral. 74:1023-1031.

Chipera S.J., D.L. Bish \& B.A. Carlos (in press). Equilibrium modeling of the formation of zeolites in fractures at Yucca Mountain, Nevada Conference Volume, Zeolite '93, D.W. Ming \& F.A. Mumpton, eds.

Holland, T.J.B 1989. Dependence of entropy on volume for silicate and oxide minerals: A review and a predictive model. Amer. Mineral. 74:5-13.

Kerrisk, J.F. 1987. Groundwater chemistry at Yucca Mountain, Nevada, and vicinity. Los Alamos National Laboratory Report LA-10929-MS.

Sawyer. D.A., RJ. Fleck, M.A. Lanphere, RG. Warren, D.E. Broxton \& M.R. Hudson 1994. Episodic Caldera Volcanism in the Miocene Southwestem Nevada Volcanic Field: Revised Stratigraphic Framework, ${ }^{40} \mathrm{Ar}^{39} \mathrm{Ar}$ Geochronology, and Implication for Magmatism and Extension. Geol. Soc. Amer. Bull. 106:1304 1318 .

Scott, R.B., RW. Spengler, S. Diehl, A.R. Lappin \& M.P. Chomack 1983. Geologic character of tuffs in the unsaturated zone at Yucca Mountain, southern Nevada: in Role of the Unsaturated Zone. in Radioactive and Hazardous Wraste Disposal. Ann Arbor Sci. Publ., Ann Arbor, Mich., 289-335.

Whelan, J.F, D.T. Vaniman, J.S. Stuckless \& R.J. Moscati 1994. Paleoclimatic and paleohydrologic records from secondary calcite: Yucca Mountain Nevada. Proc. $5^{3 /}$ Ann Intl Conf. on High Level Radioactive Waste Manag: 2738-2745, Las Vegas, Nevada. 
Multiple episodes of zeolite deposition in fractured silicic tuff

Barbara A. Carlos, Steve J. Chipera, and Marjorie G. Snow

Los Alamos National Laboratory, Mail Stop D462, Los Alamos, NM 87545

\begin{abstract}
Fractures in silicic tuffs above the water table at Yucca Mountain, Nevada, USA contain two morphologies of heulandite with different compositions. Tabular heulandite is zoned, with Sr-rich cores and $\mathrm{Mg}$-rich rims. Later prismatic heulandite is nearly the same composition as the more magnesian rims. Heulandite and stellerite may occur between layers of calcite, and calcite occurs locally between generations of heulandite. Thermodynamic modeling, using estimated thermodynamic data and observed chemical compositions for heulandite and stellerite, shows that stellerite is the favored zeolite unless Ca concentrations are reduced or $\mathrm{Mg}$ and/or $\mathrm{Sr}$ concentrations are significantly elevated above current Yucca Mountain waters.
\end{abstract}

\section{INTRODUCTION}

Yucca Mountain, in southwest Nevada, USA is composed of a $>1.5 \mathrm{~km}$-thick sequence of silicic tuffs and subordinate lavas (Scott et al., 1983; Carr et al., 1986) ranging in age from $12 \mathrm{my}$ to $>14 \mathrm{my}$ (Sawyer et al., 1994). Yucca Mountain is being investigated as a potential high-level nuclear waste repository since a repository could be located within devitrified tuff $>200 \mathrm{~m}$ below the surface of the mountain yet still be $150 \mathrm{~m}$ above the water table, and because the zeolitic tuffs beneath the potential repository provide a natural barrier to the migration of some radionuclides. Fracture-lining minerals within the unsaturated zone provide information on potential flow paths both toward and away from the potential repository; knowledge of the distribution of fracture-lining minerals is also needed to model reactions along flow paths at elevated temperatures resulting from waste emplacement.

Fracture coatings within the predominantly nonzeolitic Paintbrush Group vary both with depth and laterally across Yucca Mountain, with the most abundant fracture-lining minerals consisting of silica polymorphs (quartz, tridymite, cristobalite, opal-CT), calcite, zeolites (stellerite, heulandite, mordenite), and Mn-oxides (lithiophorite and rancieite), with lesser amounts of smectite, chain clays, fluorite, calcic amphibole, and Fe-oxides (Carlos et al., 1991, and in press). The general sequence of deposition is 1) tridymite and quartz on early fractures and lithophysal cavities, often with hematite blades and/or calcic amphibole; 2) fine grained mordenite and crusts of clay and/or manganese oxide minerals on curviplanar cooling fractures in both devitrified and vitrophyric intervals; and 3) coarse ( $>5 \mu \mathrm{m}$ crystal size) heulandite and/or stellerite, mordenite, calcite, and fine-grained clays on rougher fractures and over the minerals coating earlier fractures. Fluorite and/or opal may occur with calcite in fractures and lithophysal cavities, particularly in. shallower intervals. Stellerite and mordenite may occur over lithophysal coatings in deeper intervals. Many of the fracture coatings in the unsaturated zone were deposited early in the cooling history of the tuff (11.5-12.5 My ago), but some of the calcite, clays, and zeolites in the Paintbrush Group are more recent and therefore provide information on flow paths and transport within fractures that would be useful in predicting the behavior of the mountain after emplacement of radioactive waste.

Multiple episodes of zeolite deposition are suggested by at least two compositions and morphologies of heulandite coexisting in fractures in the unsaturated zone. Whelan et al. (1994) have shown using $\mathrm{C}$ and $\mathrm{O}$ isotopic data that calcites in unsaturated intervals precipitated from meteoric water that had interacted with soil at the surface. Carbon-14 dates obtained from calcites in the unsaturated zone range from $20.9 \mathrm{Ka}$ to $>51 \mathrm{Ka}$ (limit of the method). To better understand zeolite deposition in fractures in the unsaturated zone, fractures containing more than one morphology of heulandite, and fractures containing both calcite and zeolite were examined. In addition, thermodynamic modeling was performed to determine the nature of changing conditions required to precipitate the sequence of fracture coatings that is present at Yucca Mountain.

\section{METHODS}

Fracture coatings from drill cores at and near Yucca Mountain were examined using a binocular 
microscope at up to $50 \times$ magnification, and fragments from selected fractures were examined using an ISI scanning electron microscope (SEM) and a Tracor'Northern ADEM SEM. Backscattered electron (BSE) images of polished grain mounts and of thin sections of zeolitic coatings were used to identify zoning in the zeolites. Quantitative chemical analyses of fracture-coating zeolites were obtained using a Cameca SX-50 microprobe.

To conduct thermodynamic modeling, a consistent set of thermodynamic data utilizing representative mineral compositions from the Paintbrush Tuff (Table 1 and Chipera et al., in press) was estimated using the methods of Berman and Brown (1985), Chermak and Rimstidt (1989), and Holland (1989). Applying the Ge0-Calc PTA program of Brown et al. (1989), mineral-stability diagrams were calculated at various temperatures, silica activities, and for varying activities of the ionic species in the groundwater. Calculations were conducted projecting from water (activity $=1$ ) and any reaction or product cations were exchanged with the liquid phase. In the calculations, cation concentrations in the fluid phase were assumed to initially approximate the current concentrations measured in Yucca Mountain ground water (Kerrisk, 1987). Cation concentrations may be buffered by other reactions occurring in the natural system independent of the reactions involving zeolites (e.g., excess $\mathrm{Ca}^{2+}$ consumed to form calcite). Pressure was constrained such that all calculations were conducted on the liquid side of the water liquid-vapor curve, and $\mathrm{pH}$ values used for the calculations were constrained to $\approx 8$, a value that is representative of present-day waters at Yucca Mountain (Kerrisk, 1987). Additional thermodynamic data and methodology used are described in Chipera et al. (in press).

\section{RESULTS'AND DISCUSSION}

Fractures in the devitrified Topopah Spring Tuff contain the zeolites heulandite, stellerite, and mordenite. Heulandite occurs in fractures above the water table as both tabular and prismatic crystals. The tabular crystals are larger (usually 100-200 $\mu \mathrm{m}$ in diameter) and generally are limited to an interval of a few tens of meters above the basal vitrophyre. Chemical zonation in the tabular crystals is visible in BSE (SEM) images. Prismatic heulandite crystals are much more widely distributed in fractures and are smaller (10-50 $\mu \mathrm{m}$ long). Zonation is not evident in BSE images of prismatic crystals. Since most prismatic crystals are too small to analyze by electron microprobe it is not known if all sizes of prismatic crystals have the same composition. In fractures that contain both prismatic and tabular heulandite, the prismatic crystals partially overlie the tabular crystals.

Zoned tabular heulandites have cores richer in $\mathrm{Sr}$, $\mathrm{Ca}$, and $\mathrm{Na}$, and rims enriched in $\mathrm{Mg}$. Cation compositions of the cores of the tabular crystals

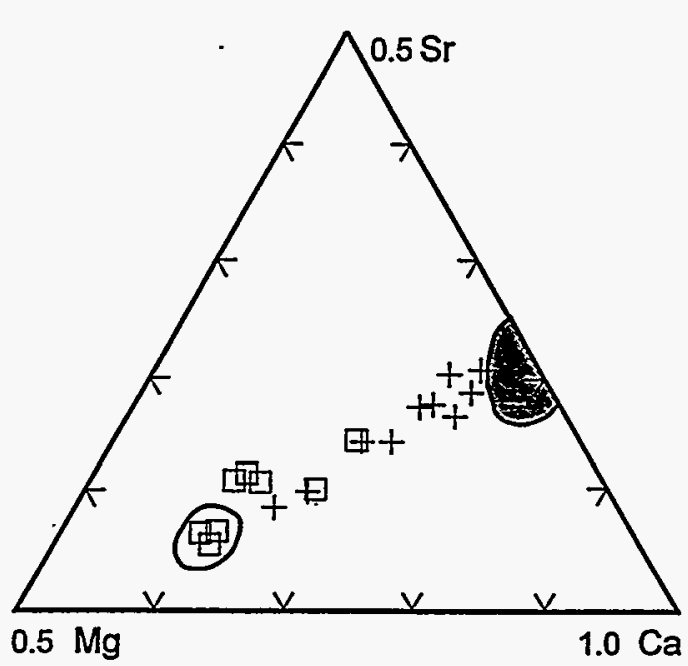

Figure 1. Ternary plot based on number of exchangeable cations, showing chemistry of prismatic heulandite crystals (open circle) and chemical zonation of tabular heulandite crystals. Shaded area represents the cores of tabular crystals, open boxes are rims and + are intermediate zones $20-40 \mu \mathrm{m}$ beneath the rims.

analyzed in this study ( 3 samples from 2 drill cores) cluster tightly on the ternary diagram in Fig. 1 . The prismatic heulandites (4 crystals from one sample) have the same composition as the rims of the tabular heulandite coexisting in that sample. Rims of tabular crystals from other samples and the zones between rims and cores plot along a trend between these two compositions. Representative compositions of the Sr-rich core, the Mg-rich rim and prismatic crystals from the same interval are given in Table 1.

Mordenite occurs both with and over heulandite (both morphologies), and may have been deposited continuously or in several episodes. Stellerite occurs as single crystals or as sprays of crystals by themselves, with prismatic heulandite, with mordenite, and rarely, with tabular heulandite.

Calcite overlies tabular heulandite in a few fractures and, in at least two samples, small prismatic zeolites occur on top of that calcite. Larger prismatic heulandites in the same samples are not in contact with the calcite. Some stellerites occur over tridymite or on matrix under calcite and appear to have been deposited early in the cooling history of the tuff. Other stellerites occur with prismatic heulandite over calcite, and were therefore deposited after that calcite and after the tabular heulandite that preceded prismatic heulandite. In some samples, additional calcite coats the stellerite theulandite. Differences in chemical composition in the stellerite have not been observed, but that may be because the structure of stellerite allows for little substitution. As there were several episodes of calcite deposition, relationship to calcite does not establish age of the zeolite unless that particular 
Table 1. Chemical analyses of zeolites.

\begin{tabular}{lcccc}
\hline \multicolumn{5}{c}{ Heulandite $^{1}$} \\
& $\begin{array}{c}\text { Tabular } \\
\text { core }\end{array}$ & rim & matic & $\begin{array}{c}\text { Pris- } \\
\text { mate }\end{array}$ \\
\hline $\mathrm{SiO}_{2}$ & 64.67 & 65.06 & 64.46 & 64.60 \\
$\mathrm{Al}_{2} \mathrm{O}_{3}$ & 15.34 & 15.61 & 14.82 & 15.33 \\
$\mathrm{MgO}^{2}$ & 0.08 & 1.86 & 1.86 & - \\
$\mathrm{CaO}$ & 5.86 & 4.83 & 4.73 & 8.29 \\
$\mathrm{SrO}$ & 2.53 & 1.06 & 0.88 & - \\
$\mathrm{Na}_{2} \mathrm{O}$ & 0.64 & 0.22 & 0.29 & 0.15 \\
$\mathrm{~K}_{2} \mathrm{O}$ & 0.41 & 0.17 & 0.17 & 0.08 \\
$\mathrm{Total}$ & 89.53 & 88.81 & 87.21 & 88.45 \\
& & & & \\
$\mathrm{Si}$ & 28.18 & 28.12 & 28.32 & 28.12 \\
$\mathrm{Al}$ & 7.88 & 7.95 & 7.67 & 7.87 \\
$\mathrm{Mg}$ & 0.05 & 1.20 & 1.22 & - \\
$\mathrm{Ca}$ & 2.74 & 2.24 & 2.23 & 3.87 \\
$\mathrm{Sr}$ & 0.64 & 0.27 & 0.22 & - \\
$\mathrm{Na}$ & 0.54 & 0.18 & 0.25 & 0.13 \\
$\mathrm{~K}$ & 0.23 & 0.09 & 0.10 & 0.04 \\
$\mathrm{O}$ & 72 & 72 & 72 & 72 \\
$\mathrm{Si} / \mathrm{Al}$ & 3.58 & 3.54 & 3.69 & 3.58 \\
\hline TE-25a\#1 1243 & & & \\
${ }^{2}$ USW G-2 1505 & & &
\end{tabular}

calcite has been dated.

Between deposition of the tabular heulandite and prismatic heulandite, the fluid composition must have changed. The compositional boundaries between rims and cores of tabular crystals are not sharp growth boundaries, but somewhat variable (Fig. 2) and appear to indicate diffusion from the edges and along cracks or imperfections in the crystals. The zonation is not of equal width around the edges of crystals and appears to have been influenced by crystallographic orientation. A sharper and more regular zonation boundary would have resulted from overgrowths on the tabular crystals. SEM images indicate that when more

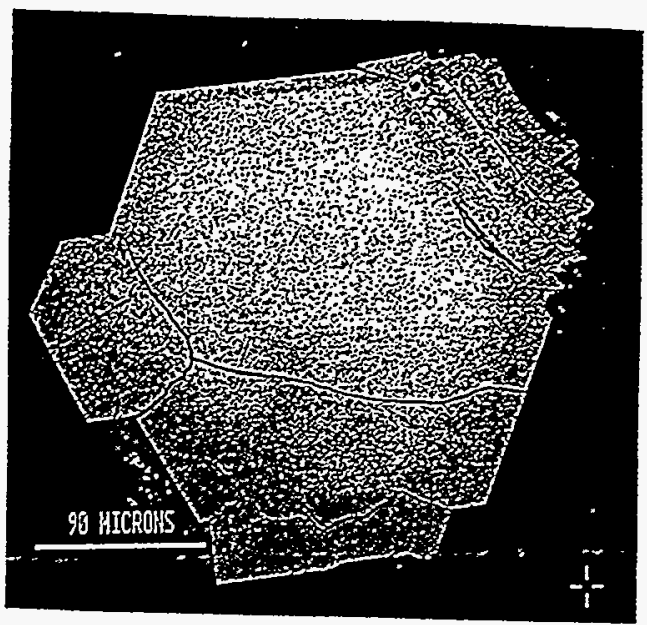

Figure 2. Backscattered electron SEM image of zoned tabular heulandite showing irregular pattern of $\mathrm{Mg}$ enrichment (darker areas). magnesian heulandite was deposited on existing tabular crystals, it formed prismatic crystals on the surface of the tabular crystals. The intermediate compositions in the visibly zoned areas between the rims and the core, and the intermediate compositions of some rims could indicate a gradual change in composition of the fluid, but the pattern of $\mathrm{Mg}$ distribution observed in BSE images and the consistent relationship of chemistry with morphology suggest two separate intervals of heulandite deposition with different fluid compositions and diffusion into the tabular crystals rather than a gradual change in fluid composition over time.

Results of thermodynamic modeling show that silica activity has a strong control over. whether stellerite and/or heulandite form relative to other zeolites (e.g., clinoptilolite and mordenite). Figure 3 shows the effect of silica activity and the calculated equilibria using $\log \left[\left(a \mathrm{~K}^{+}\right)^{2} / a \mathrm{Ca}^{2+}\right]$ vs. $\log \left[\left(a \mathrm{Na}^{2}\right)^{2} / a \mathrm{Ca}^{2+}\right]$ for zeolites found at Yucca Mountain. Present-day cation concentrations in Yucca Mountain waters are plotted on the figure for reference. At elevated silica activities (e.g., equilibrated with amorphous silica), clinoptilolite and mordenite are the zeolites that are most likely to form. At lower silica activities (e.g., equilibrated with cristobalite or tridymite) stellerite and/or heulandite are the zeolites most likely to form. Stellerite and heulandite coexist in some fractures and have similar $\mathrm{Si} / \mathrm{Al}$ ratios, so it is not surprising that modeling of silica activities does not differentiate between the two minerals. Silica activities in the fractures are most likely in equilibrium with cristobalite or quartz as indicated by the coexistence of these silica polymorphs with

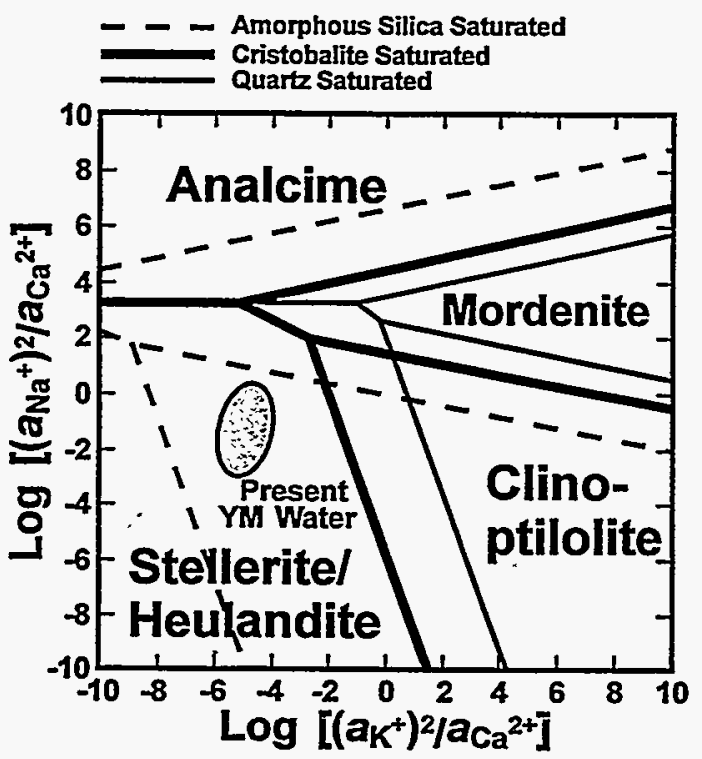

Figure 3. $\mathrm{Log}\left[\left(a \mathrm{~K}^{+}\right)^{2} / a \mathrm{Ca}^{2+}\right]$ vs. $\log \left[\left(a \mathrm{Na}^{+}\right)^{2} / \mathrm{aCa}^{2+}\right]$ diagrams for zeolite phases found at Yucca Mountain constructed at $75^{\circ} \mathrm{C}$ and at variable silica activities. 
stellerite and heulandite in some fractures. Figure 3 also demonstrates the influence of cation composition on the formation of individual zeolite species. The exact stability fields can differ markedly in response to the cation ratios in the zeolites used for the calculations.

The dominant control on heulandite vs. stellerite deposition was found to be the concentration of the various dissolved cation species in the ground water. In the calculations, stellerite was the stable zeolite to form unless $\mathrm{Ca}$ concentration was significantly reduced with respect to current concentrations, or $\mathrm{Sr}$ and/or $\mathrm{Mg}$ content was increased. The presence of calcite coexisting in the fractures allows ready calculation of $\mathrm{Ca}$ concentration given $\mathrm{pH}$, temperature, and bicarbonate concentration, and constrains $\mathrm{Ca}^{2+}$ to concentrations roughly equivalent to current Yucca Mountain values.

Increasing temperature to $175^{\circ} \mathrm{C}$ in the calculations showed only minor effects. With increased temperature at a given silica saturation, the stability fields for mordenite and clinoptilolite decrease slightly as the stellerite/heulandite stability fields increases. Increasing temperature also affected the calcite-Ca ${ }^{2+}$ equilibria such that it reduced the activity of $\mathrm{Ca}^{2+}$, which would favor the deposition of heulandite at higher temperatures.

\section{CONCLUSIONS}

Chemical compositions of heulandite suggest two generations of zeolite deposition in these fractures, and morphological evidence suggests that there may be three; the presence of stellerite and/or heulandite both over and under calcite establishes that there were at least two episodes. Whether all zeolite deposition occurred soon after deposition of the tuff, or whether some zeolite deposition is more recent may be determined by dating of calcite that occurs under some zeolites.

Results of thermodynamic modeling show that although silica activity controls whether stelleriteheulandite or clinoptilolite-mordenite will form, it has little effect on stellerite-heulandite equilibria. Activities of the cation species in the groundwater exert the most control on the formation of stellerite vs. heulandite. Stellerite is the favored zeolite to form unless $\mathrm{Ca}$ concentrations are significantly reduced or $\mathrm{Mg}$ and/or $\mathrm{Sr}$ concentrations significantly elevated, whereupon heulandite is favored. Since $\mathrm{Ca}$ concentration was buffered by the abundant calcite seen in the fractures, it appears that the $\mathrm{Mg}$ and $\mathrm{Sr}$ concentrations were elevated to values greater than in present Yucca Mountain groundwaters. This could be accomplished through either increased dissolution in the rocks or concentration of dissolved species in solution.

\section{REFERENCES}

Berman, R.G. \& T.H. Brown 1985. Heat capacity of minerals in the system $\mathrm{Na}_{2} \mathrm{O}-\mathrm{K}_{2} \mathrm{O}-\mathrm{CaO}-\mathrm{MgO}$ $\mathrm{FeO}-\mathrm{Fe}_{2} \mathrm{O}_{3}-\mathrm{Al}_{2} \mathrm{O}_{3}-\mathrm{SiO}_{2}-\mathrm{TiO}_{2}-\mathrm{H}_{2} \mathrm{O}-\mathrm{CO}_{2}$ : representation, estimation, and high temperature extrapolation. Contr. Mineral. \& Petrol. 89:168183.

Brown, T.H., R.G. Berman \& E.H. Perkins 1989. PTA-SYSTEM: A Ge0-Calc software package for the calculation and display of activitytemperature-pressure phase diagrams. Amer. Mineral. 74:485-487.

Carlos, B.A., S.J. Chipera, D.L. Bish \& R. Raymond (in press). Distribution and chemistry of fracture-lining zeolites at Yucca Mountain, Nevada. Conference Volume, Zeolite '93, D.W. Ming \& F.A. Mumpton, eds.

Carlos, B.A., D.L. Bish \& S.J. Chipera 1991. Fracture-lining minerals in the Lower Topopah Spring Tuff at Yucca Mountain. Proc. $2^{\text {nd }}$ Ann. Int. Conf. High Level Radioactive Waste Manag: 486-493., Las Vegas, Nevada.

Carr, W.J., F.M. Byers Jr. \& P.P. Orkild 1986. Stratigraphic and volcano-tectonic relations of Crater Flat Tuff and some older volcanic units, Nye County, Nevada. U.S. Geol. Surv. Prof. Paper, 1323.

Chermak, J.A. \& J.D. Rimstidt 1989. Estimating the thermodynamic properties $\left(\Delta \mathrm{G}_{\mathrm{f}}^{\circ}\right.$ and $\left.\Delta \mathrm{H}^{\circ}\right)$ of silicate minerals at $298 \mathrm{~K}$ from the sum of polyhedral contributions. Amer. Mineral. 74:1023-1031.

Chipera, S.J., D.L. Bish \& B.A. Carlos (in press). Equilibrium modeling of the formation of zeolites in fractures at Yucca Mountain, Nevada. Conference Volume, Zeolite '93, D.W. Ming \& F.A. Mumpton, eds.

Holland, T.J.B 1989. Dependence of entropy on volume for silicate and oxide minerals: A review and a predictive model. Amer. Mineral. 74:5-13.

Kerrisk, J.F. 1987. Groundwater chemistry at Yucca Mountain, Nevada, and vicinity. Los Alamos National Laboratory Report LA-10929-MS.

Sawyer. D.A., R.J. Fleck, M.A. Lanphere, R.G. Warren, D.E. Broxton \& M.R. Hudson 1994. Episodic Caldera Volcanism in the Miocene Southwestern Nevada Volcanic Field: Revised Stratigraphic Framework, ${ }^{40} \mathrm{Ar} /{ }^{39} \mathrm{Ar}$ Geochronology, and Implication for Magmatism and Extension. Geol. Soc. Amer. Bull. 106:13041318.

Scott, R.B., R.W. Spengler, S. Diehl, A.R. Lappin \& M.P. Chornack 1983. Geologic character of tuffs in the unsaturated zone at Yucca Mountain, southem Nevada: in Role of the Unsaturated Zone. in Radioactive and Hazardous Waste Disposal. Ann Arbor Sci. Publ., Ann Arbor, Mich., 289-335.

Whelan, J.F, D.T. Vaniman, J.S. Stuckless \& R.J. Moscati 1994. Paleoclimatic and paleohydrologic records from secondary calcite: Yucca Mountain, Nevada. Proc. $5^{\text {th }}$ Ann. Intl Conf. on High Level Radioactive Waste Manag: 2738-2745, Las Vegas, Nevada. 